\title{
The evolution of marketing research topics in developing countries over the decade: evidence from the Middle East
}

\author{
Ghaith M. Al-Abdallah \\ American University of Madaba, Jordan
}

\begin{abstract}
Marketing and business research topics vary between the different regions of the world, while developed and welldeveloped countries are leading the world scientific research, developing countries need to focus on research relevant to their situation. This, in many cases, means doing research that has been already covered in developed countries. While the genuine (new-to-the-world) level of such research may not be high, the contribution to the theoretical and practical knowledge about developing countries is very important. Many elite journals do not understand this point clearly, and some of them would reject a research from a developing country because it has been covered in developed ones. However, the results obtained from such research may not be the same, not to mention that the interpretation of such results could be very different. Accordingly, researchers in developing countries may end up repeating some to the examined topics in developed countries but with special focus on their own markets macroenvironment and special circumstances, this would provide insightful understanding of these markets even if the topic itself is not considered new in the academic community. Therefore, the leading research topics covered in developing countries during the past decade are very different from the one covered in developed countries. In this editorial we will go through the main trends that dominate the marketing research in developing countries in the Middle East. We will follow my colleagues and I research of active and contemporary topics in the Middle East starting 2010 till the end of 2020.
\end{abstract}

As the markets were recovering after the 2008 crises, and with the support of international funds, examining the feasibility of establishing new business was an important topic to address, a good example on this trend would be Abou-Moghli \& Alabdallah (2012) study entitled "Market Analysis and the Feasibility of Establishing Small Businesses".

After that, an emerging topic at early 2010 started to rise; internet adoption and internet implications on different aspects of business became the main trend in scholarly research, a good example of the most read papers on ResearchGate would be "The Effect of Promotional Mix on Internet Adoption in Jordanian Small and Medium Enterprises" (Alabdallah \& Abou-Moghli, 2012) and "Internet Marketing Research and Competitive Advantage" (Al-Abdallah, 2014) which was discussed in the International Conference for Academic
Disciplines at $\mathrm{Ca}$ ' Foscari University, Venice, Italy and "The Impact of Internet Marketing Research on Achieving Competitive Advantage" (Alabdallah, 2015). Another example is "The Effect of Customer-Company Relationship on Internet Adoption in Jordanian Small and Medium Enterprises" (Al-Abdallah, 2013) which was discussed at the Second International Conference on Global Business Environment, International Foundation for Research and Development, Bangkok, Thailand which evolved into an important research papers entitled "Customer Relationship Management and Internet Implementation" (Alabdallah, 2013a) and "The Effect of Customer-Company Relationship on Internet Adoption in Jordanian Small and Medium Enterprises" (Alabdallah, 2013b). The research around internet remained the most dominant research area years to come, new variables and dimensions were included, demonstrating the natural progress in this regard and extending the impact of such research, for instance Alabdallah, Al-Khawaldeh \& Al-Hadid (2014) examined the moderating effect of the firm's size on the internet usage impact on traditional distribution channels. More advance topics were introduced in this area, specific and deeper investigations related to internet were addressed, a perfect example signaling such advancement would be Al-Abdallah, Abou-Moghli \& Al-Thani (2018) examination of the ecommerce technology drivers in the real estate industry in Qatar, where adoption and drives for use were analyzed and understood in several vital sectors as well.

Because social media became an important part of our daily lives in both personal and professional levels, research in this filed became, and still to date, the obsession of marketing researcher in developing countries in general, and Middle East in particular, research on the determinants of continuance intention to use social networking sites (Bataineh, Alabdallah \& Alkharabsheh, 2015) and research on the impact of social networking sites on the purchasing process (Al-Abdallah \& Bataineh, 2018) reflected a wide range of topics covered starting with the use all the way to full business transactions. The evaluation of traditional communication channels in light of social media and new technologies became an interesting topic to understand as well (Mustafa \& Al-Abdallah, 2020).

Since the financial sector is perhaps the most important sector in most developing countries, as it drives the economy in such 
markets, examining how this sector can perform better through innovation in process and management became a hot topic in 2012 and afterword, a good example would be AbouMoghli, Alabdallah \& Muala (2012) study on the impact of innovation on realizing competitive advantage in banking sector, and Al-Hourani, Al-Abdallah \& Abou-Moghli, (2013) paper on the organizational factors affecting administrative problem solving in the commercial banks, which was discussed at the Western Business and Management Association Annual Conference, Rome, Italy. New technologies and digital channels were also important to understand, as this sector has the capabilities to adapt similar technologies faster than other sectors. Accordingly, studies about mobile banking (Al-Abdallah, 2015), internet banking adoption, behavioral approaches, and website design and usage behavior models for digital banking" (Al Qeisi \& Alabdallah, 2013; 2014) were among the most important research in this filed.

At the early 2010, telecommunication sector was booming in the Middle East, many studies examining the factors affecting the selection of services providers and mobile devices were interesting research areas, Alabdallah \& Aborumman (2012) study on the effect of brand associations on customer loyalty for mobile devices exemplify studies of this period. Another example would be Al-Abdallah \& Ahmed (2018) research on the impact of corporate social responsibility on customer loyalty in the Qatari telecommunication sector. Bataineh et al. (2016) also examined the evolving role of information technology in capitalizing market agility in Jordanian telecommunications sector.

Old-new topics such as marketing audit, the role of the disclosure and transparency in combating financial and administrative corruption, and organizational culture and total quality management stayed the focus of many researchers during the past 10 years (Al-Bourini, Al-Abdallah \& AbouMoghli, 2013; Abou-Moghli, Al-Moumany \& Alabdallah, 2013). Factors affecting customers' selection and studies on the moderating effect of demographics remained appealing to a several important scholars as deeper understanding of these issues was required (Ghattas \& Al-Abdallah, 2020).

Relationship studies had a significant share of research in the past ten years, research ranging from the effect of relationship marketing on customer retention, to the Impact of supplier relationship management on competitive performance (Bataineh, Alabdallah, Gh., Salhab \& Shoter, 2015; Alabdallah, Abdallah \& Bany-Hamdan, 2014; Al-Abdallah \& Chew, 2019) presented the importance of such research areas.

Then again, the emerging topics in developed countries have affected the research in developing countries. For instance, with the increase of interest in entrepreneurship studies in the developed countries, basic research in this filed draw the attention of several researchers in the Middle East, research on evaluating the association between corporate entrepreneurship and firm performance (Abou-Moghli \& Al-
Abdallah, 2018) and women entrepreneurs' opportunities and challenges in conservative and traditional societies such as Saudi Arabia (Abou-Moghli \& Al-Abdallah, 2019), were among the most read research in 2019. Research on Internal Marketing and the Productivity of Employees was the main topic discussed in the fourth International Scientific Conference of Arab University, Amman - Jordan (AlAbdallah, 2019) driving the interest in this filed in different sectors based on the orientation of similar research in developed countries.

Other research areas are available for sure but the focus of this editorial was on the main research topics with the highest read (and mention) in academic sites, mainly ResearcGate and Academia.

Ten years from now, it will be absolutely interesting to look back at the main research directions and orientation in the Middle East and to prepare a comparison between what was interesting now and what will be interesting then to draw a path of research development in the region!

\section{REFERENCES}

[1] Abou-Moghli, A. \& Al-Abdallah, Gh., (2018), Evaluating The Association Between Corporate Entrepreneurship and Firm Performance, International Journal of Entrepreneurship; Vol. 22, No. 4, pp. 1-10.

[2] Abou-Moghli, A. Alabdallah,Gh., \& Muala, A. (2012) Impact of Innovation on Realizing Competitive Advantage in Banking Sector in Jordan. American Academic \& Scholarly Research Journal; Vol. 4, No. 5, pp. 209-217.

[3] Abou-Moghli, A., Al-Moumany, S., \& Alabdallah, Gh. (2013) The Role of the Disclosure and Transparency in Combating Financial and Administrative Corruption: A Field Study on Jordanian Public Joint-Stock Industrial Companies listed in Amman Stock Market. Interdisciplinary Journal of Contemporary Research in Business; Vol. 5, No. 4, pp. 368-381.

[4] Abou-Moghli, A.A. \& Al-Abdallah, G.M. (2019). A systematic review of women entrepreneurs' opportunities and challenges in Saudi Arab. Journal of Entrepreneurship Education, 22(6).

[5] Al Qeisi, K., \& Alabdallah, Gh. (2013) Internet Banking Adoption in Jordan: A Behavioral Approach, International Journal of Marketing Studies; Vol. 5, No. 6, pp. 84-108.

[6] Al Qeisi, K., \& Alabdallah, Gh. (2014) Website Design and Usage Behaviour: An Application of the UTAUT Model for Internet Banking in UK, International Journal of Marketing Studies; Vol. 6, No. 1, pp. 75-89.

[7] Alabdallah, Gh. \& Aborumman, A. (2012) The Effect of Brand Associations on Customer Loyalty: Empirical Study on Mobile Devices in Jordan. American Academic \& Scholarly Research Journal; Vol. 5, No. 1, pp. 122-134.

[8] Al-Abdallah, Gh. \& Bataineh, A. (2018) Social Networking Sites and Fashion E-Purchasing Process, Journal of Business \& Retail Management Research; Vol. 13 No. 2, pp. 36-49.

[9] Al-Abdallah, Gh. \& Chew, V. (2019) Barriers to Six Sigma implementation in Chinese small and medium steel enterprises, Accepted at: International Journal of Business Excellence, Vol. 21, No. 4, pp. 454-466.

[10] Alabdallah, Gh. (2013) Customer Relationship Management and Internet Implementation: Empirical Study on local Jordanian Enterprises. Interdisciplinary Journal of Contemporary Research in Business; Vol. 5, No. 4, pp. 44-56.

[11] Alabdallah, Gh. (2013) The Effect of Customer-Company Relationship on Internet Adoption in Jordanian Small and Medium Enterprises, Journal of Economics and Behavioral Studies; Vol. 5, No. 4, pp. 192-199. 
[12] Alabdallah, Gh. (2015) The Impact of Internet Marketing Research on Achieving Competitive Advantage, International Journal of Arts \& Sciences; Vol. 8, No. 1, pp. 619-627.

[13] Alabdallah, Gh., \& Abou-Moghli, A. (2012) Market Analysis and the Feasibility of Establishing Small Businesses. European Scientific Journal; Vol. 8, No. 9, pp. 94-113.

[14] Alabdallah, Gh., \& Abou-Moghli, A. (2012) The Effect of Promotional Mix on Internet Adoption in Jordanian Small and Medium Enterprises. European Scientific Journal; Vol. 8, No. 12, pp. 96-112.

[15] Al-Abdallah, Gh., \& Ahmed, R. (2018) The Impact of Corporate Social Responsibility on Customer Loyalty in the Qatari Telecommunication Sector, Journal of Business \& Retail Management Research; Vol. 13 No. 1, pp. 253-268.

[16] Alabdallah, Gh., Abdallah, A., \& Bany-Hamdan, A. (2014) The Impact of Supplier Relationship Management on Competitive Performance of Manufacturing Firms, International Journal of Business and Management; Vol. 9, No. 2; pp. 192-202.

[17] Al-Abdallah, Gh., Abou-Moghli, A. \& Al-Thani, A. (2018), An Examination of the e-commerce Technology Drivers in the Real Estate Industry, Problems and Perspectives in Management, Volume 16, Issue 4, 2018; Vol. 16 No. 4, pp. 1-27.

[18] Alabdallah, Gh., Al-Khawaldeh, K., \& Al-Hadid, A. (2014) Internet Usage and Traditional Distribution Channels: The Moderating Effect of the Firm's Size in Jordan, International Business Research Journal; Vol. 7, No. 3, pp. 81-90.

[19] Al-Bourini, F., Al-Abdallah, Gh., \& Abou-Moghli, A. (2013) Organizational Culture and Total Quality. Management, International Journal of Business and Management; Vol. 8, No. 24, pp. 95-106.

[20] Bataineh, A., Alabdallah, Gh., \& Alkharabsheh, A. (2015) Determinants of Continuance Intention to Use Social Networking Sites SNS: Studying the Case of Facebook, International Journal of Marketing Studies; Vol. 7, No. 4, pp. 121-135.

[21] Bataineh, A., Alabdallah, Gh., Salhab, H., \& Shoter, A. (2015) The Effect of Relationship Marketing on Customer Retention in the Jordanian Pharmaceutical Sector, International Journal of Business and Management; Vol. 10, No. 3, pp. 117-131.

[22] Bataineh, A., Alhadid, A., Alabdallah, Gh., \& Alfalah, T. (2016) The Role of Information Technology Capabilities in Capitalizing Market Agility in Jordanian Telecommunications Sector, International Journal of Academic Research in Business and Social Sciences; Vol. 5, No. 8, pp. 90-101.

[23] Ghattas, D. \& Al-Abdallah, G. (2020) Factors affecting customers' selection of community pharmacies: The mediating effect of branded pharmacies and the moderating effect of demographics, Management Science Letters, Vol. 10, No. 8, pp. 1-12.

[24] Mustafa, S. \& Al-Abdallah, Gh. (2020) The evaluation of traditional communication channels and its impact on purchase decision, Management Science Letters, Vol. 10, No. 7, pp. 1-12.

\section{CONFERENCES}

[25] Al-Abdallah, Gh. (2013) the Effect of Customer-Company Relationship on Internet Adoption in Jordanian Small and Medium Enterprises. Paper abstract presented at the Second International Conference on Global Business Environment, International Foundation for Research and Development, Bangkok, Thailand.

[26] Al-Abdallah, Gh. (2014), Internet Marketing Research and Competitive Advantage. Paper presented at the International Conference for Academic Disciplines, Ca' Foscari University, Venice, Italy.

[27] Al-Abdallah, Gh. (2015), A Modified Delone \& Mclean Model for Mobile Banking. Paper presented at the 18th International Academic Conference, London, UK.

[28] Al-Abdallah, Gh. (2019), Internal Marketing and the Productivity of Employees in the Industrial Enterprises in Jordan. Paper presented at the 4th International Scientific Conference, Amman Arab University, Amman - Jordan.

[29] Al-Hourani, N., Al-Abdallah, Gh. \& Abou-Moghli, A. (2013), The Effect of Organizational Factors on Administrative Problem Solving in the Jordanian Commercial Banks. Paper presented at the Western Business and Management Association Annual Conference, Rome, Italy. 